\title{
PEMBERDAYAAN PELAYANAN DAN TATA KELOLA KEARSIPAN DI KELURAHAN MERJOSARI KOTA MALANG
}

\section{EMPOWERMENT OF ARCHIEVE SERVICES AND MANAGEMENT IN KELURAHAN MERJOSARI, KOTA MALANG}

\author{
Lely Indah Mindarti ${ }^{\# 1}$, Choirul Saleh ${ }^{\# 2}$, Aulia Puspaning Galih ${ }^{* 3}$ \\ ${ }^{\# 12}$ Program Studi Administrasi Publik, Fakultas Ilmu Administrasi, Universitas Brawijaya \\ *3Program Studi Ilmu Perpustakaan, Fakultas Ilmu Administrasi, Universitas Brawijaya

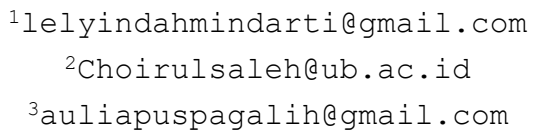

Abstrak

Artikel ini bertujuan untuk memberikan pengetahuan dan wawasan terkait pemberdayaan pelayanan dan tata kelola kearsipan pemerintah desa yang dilakukan oleh tim pengabdian di Kelurahan Merjosari Kota Malang. Tim pengabdian melakukan pelatihan dan pendampingan dalam tata kelola arsip di pemerintah desa agar peserta pelatihan memahami manfaat pentingnya pengelolaan dokumen dan arsip daerah; peserta mendapatkan keterampilan mengenai tata kelola arsip yang benar. Artikel ini ditunjukkan untuk pegawai pemerintahan desa agar memiliki pengetahuan dan kemampuan mengenai tata kelola pemerintahan desa dan memiliki kemampuan untuk melakukan pengarsipan di pemerintahan desa.

Kata kunci- Administrasi Publik, Pelayanan Publik, Pemerintah Desa, Tatakelola kearsipan

Abstract
This article aims to provide knowledge and insights related to empowerment of services and governance of village government archives carried out by the community service team in Merjosari Urban Village, Malang. The dedication team conducts training and assistance in managing archives in the village government so that the trainees understand the importance of managing local documents and archives; participants gain skills in proper records management. This article is intended for village government officials to have knowledge and abilities regarding village governance and have the ability to archive in village government.

Keywords- Public Administration, Public Services, Village Government, Archival Management

\section{PENDAHULUAN}

Setiap organisasi dan institusi memiliki data dan informasi yang disimpan untuk kepentingan lembaga. Keefektifan manajemen dibutuhkan untuk mencapai tujuan organisasi, dan hal itu akan selalu membutuhkan data dan informasi. Parameter informasi yang bermanfaat, yaitu kuantitas informasi, isi informasi, struktur informasi, bahasa atau kode yang mengungkapkan informasi, rentang waktu hidup informasi[1] . Informasi yang tersedia harus dapat dimanfaatkan setiap saat kapan pun dibutuhkan. Bentuk informasi dapat berupa catatan, rekaman aktivitas, bukti tertulis akan sebuah organisasi, hal ini biasa disebut arsip.

Arsip menurut Pasal 1 Undang-Undang Nomor 43 Tahun 2009 tentang Kearsipan adalah rekaman kegiatan atau peristiwa dalam berbagai bentuk dan media sesuai dengan perkembangan teknologi informasi dan komunikasi yang dibuat dan diterima oleh lembaga negara, pemerintahan daerah, lembaga pendidikan, perusahaan, organisasi politik, organisasi kemasyarakatan, dan perseorangan dalam pelaksanaan kehidupan bermasyarakat, berbangsa, dan bernegara.

Arsip harus bersifat autentik, informasinya utuh, berdasarkan azas asal usul dan aturan asli sehingga dapat digunakan sebagai alat bukti yang sah.Dengan perkembangan teknologi, arsip sekarang dapat berbentuk video, audio dan digital. Arsip dapat menjadi bukti yang bagi suatu tindakan dan keputusan karena sifatnya yang asli dan sah tersebut.Arsip sebagai ingatan, sumber sejarah, dan pusat informasi, sudah seharusnya dikelola sebaik mungkin agar kegiatan tertib administrasi berjalan dengan lancar dan tercipta pelayanan publik yang efektif dan efisien.

Efektivitas pengelolaan arsip di setiap instansi dipengaruhi oleh beberapa faktor, seperti kurangnya kesadaran para pegawai akan pentingnya tata kelola arsip, dan kurangnya pengetahuan dan keterampilan aparat setempat dalam mengelola dokumen dan arsip. Salah satu instansi di kota Malang yang tata kelola arsipnya kurang maksimal adalah Kelurahan Merjosari. 
Kelurahan Merjosari didirikan berdasarkan Perda 11 Tahun 2000 yang terletak di kecamatan Lowokwaru, kota Malang. Penduduk kelurahan Merjosari berjumlah 18.121 jiwa dengan $5.257 \mathrm{KK}$ (https://kelmerjosari. malangkota.go.id/) .Dari jumlah penduduk tersebut, 11.609 orang adalah penduduk dalam usia produktif (15-65 tahun ), terbanyak kedua adalah penduduk berusia $0-15$ tahun (anak-anak hingga remaja) sejumlah 5.675 jiwa, sedangkan sisanya adalah penduduk berusia 65 ke atas dengan jumlah 576 jiwa. Mata pencaharian penduduk kelurahan Merjosari adalah sebagai berikut:

$\begin{array}{lll}\text { 1. } & \text { Pegawai Negeri Sipil } & : 1.525 \text { orang } \\ \text { 2. TNI / POLRI } & : 58 \text { orang } \\ \text { 3. Karyawan Swasta } & : 49 \text { orang } \\ \text { 4. Wiraswasta / pedagang } & : 348 \text { orang } \\ \text { 5. Tani } & : 118 \text { orang } \\ \text { 6. Pertukangan } & : 1154 \text { orang } \\ \text { 7. Buruh tani } & : 169 \text { orang } \\ \text { 8. Pensiunan } & : 597 \text { orang } \\ \text { 9. Nelayan } & : 0 \text { orang } \\ \text { 10. Pemulung } & : 0 \text { orang } \\ \text { 11. Jasa } & : 42 \text { orang }\end{array}$

Kelurahan Merjosari adalah salah satu kelurahan di kecamatan Lowokwaru, kota Malang yang memiliki tujuan memudahkan masyarakat mengakses informasi yang dimiliki dengan bebas, hal ini dibuktikan dengan pembuatan laman yang dapat diakses secara luas (https://kelmerjosari.malangkota.go.id/), tetapi informasi yang dibutuhkan masyarakat bukan hanya gambaran umum mengenai kelurahan Merjosari, melainkan lebih pada pelayanan publik agar memudahkan masyarakat mendapatkan surat yang mereka inginkan, antara lain pembuatan KTP, surat pindah, surat kelahiran, surat kematian, dan lain sebagainya.

Jenis dokumen yang masyarakat butuhkan telah memiliki standar operasional prosedur (SOP) yang tertuang dalam Keputusan Lurah Merjosari nomor 188.45 tahun 2014 tentang Penetapan Standar Operasional Prosedur (SOP) Kelurahan Merjosari Kota Malang. SOP yang dibuat adalah sebagai berikut: 1. SOP Kartu Tanda Penduduk (KTP);

2. SOP Kartu Keluarga (KK);

3. SOP Surat Keterangan Umum Kependudukan;

4. SOP Surat Pindah Keluar;

5. SOP Surat Pindah Datang;

6. SOP Surat Keterangan Catatan Kepolisian

(SKCK);

7. SOP Surat Keterangan Model C;

8. SOP Legalisir/Legalisasi Dokumen;

9. SOP Surat Kelahiran;

10. SOP Surat Kematian;

11. SOP Pengantar Nikah;

12. SOP Surat Keterangan Tidak Mampu;
13. SOP Surat Keterangan Usaha (UKM);

14. SOP Pengantar HO;

15. SOP Pengantar Ijin Mendirikan Bangunan

(IMB);

16. SOP Surat Keterangan Usaha/Domisili (Badan

Hukum)

17. SOP Surat Keterangan Umum Ketertiban; dan

18. SOP PPAT/ Surat Keterangan Umum

Pertanahan.

Dari 18 SOP yang disebutkan dalam Keputusan Lurah Merjosari nomor 188.45 tahun 2014 tersebut, tidak ada SOP mengenai tertib administrasi yang berfokus pada pengelolaan arsip. Padahal banyak kasus yang terjadi adalah dikarenakan kurangnya pemahaman dan kemampuan aparat kelurahan dalam menangani arsip sehingga pelayanan kepada masyarakat kurang maksimal. Contoh kasusnya adalah penyimpanan dokumen yang tidak tertata sehingga para pegawai di kelurahan Merjosari kota Malang mengalami kesulitan untuk menemukan kembali dokumen yang dibutuhkan. Hal tersebut dikarenakan pegawai kelurahan Merjosari hanya meletakkan dokumen yang sudah selesai tanpa berurutan sesuai abjad apabila masyarakat datang kekelurahan untuk mengambil e-KTP, Surat Keterangan Lahir, Surat Keterangan Pindah, ataupun surat yang lain, mereka harus menunggu karena aparat kelurahan di kelurahan Merjosari sibuk mencari dokumen yang namanya tercantum pada surat tanda bukti pengambilan.

Desa/kelurahan memiliki banyak data dan informasi yang dibutuhkan untuk mengatasi permasalahan yang ada dan membantu kebutuhan masyarakat sekitar, tetapi kearsipan di kelurahan Merjosari kecamatan Lowokwaru, kota Malang kurang tertata dengan baik sehingga pelayanan kepada masyarakat menjadi kurang maksimal.Para pengelola pemerintahan di tingkat kelurahan belum memiliki kesadaran mengenai pentingnya tata kelola arsip sebagai bagian dari tertib administrasi yang seharusnya dijalankan. Selain itu, aparat kelurahan juga belum memiliki kemampuan dan keterampilan tata kelola arsip yang baik dan benar.

Tata kelola arsip yang buruk dapat menghambat layanan yang diberikan kepada masyarakat, untuk itu diperlukan pendidikan mengenai pentingnya tata kelola arsip dalam pelayanan publik dan pendampingan sistem kearsipan kepada aparat kelurahan. Apabila aparat kelurahan menata dokumen dan arsip dengan baik, maka secara otomatis kebutuhan masyarakat dan kelurahan pada umumnya akan terpenuhi dengan efektif dan efisien. Oleh karena itulah pengabdian dengan judul Pemberdayaan Pelayanan dan Tata Kelola Kearsipan di Kelurahan Merjosari Kota Malang ini dibuat dan dilaksanakan. 


\section{TARGET DAN LUARAN}

\subsection{Target Kegiatan}

Dalam program pengabdian yang berbentuk pelatihan dan pendampingan dalam tata kelola arsip di kelurahan ini mempunyai sasaran yaitu seluruh pegawai pemerintah kelurahan Merjosari yang berkaitan dengan pelayanan dan pengelolaan arsip. target yang ingin dicapai dari pengabdian ini adalah:

1. Peserta pelatihan memahami manfaat pentingnya pengelolaan dokumen dan arsip daerah sehingga dapat berguna untuk melayani masyarakat dengan efektif dan efisien.

2. Peserta mendapatkan keterampilan mengenai tata kelola arsip yang benar dengan adanya pendampingan dari dari tim pengabdian sehingga arsip yang berada di kelurahan dapat lebih tertata dan mudah dimanfaatkan oleh setiap khalayak.

Masyarakat kelurahan Merjosari bisa mendapatkan pelayanan yang lebih baik dari aparat pemerintahan kelurahan yang telah memahami pentingnya tertib administrasi, dalam hal ini terkait dengan kearsipan.

\subsection{Luaran Kegiatan}

Luaran dari kegiatan pengabdian kepada masyarakat ini adalah:

1. Akademik

a. Untuk memperkaya khasanah konsep dan teori tentang pengelolaan desa dan kearsipan di pemerintahan desa.

b. Mengembangkan strategi tentang pengelolaan pemerintah desa dan kearsipan yang terdapat di pemerintahan desa.

2. Praktis

a. Pegawai kelurahan memiliki pengetahuan mengenai tata kelola pemerintahan desa dan memiliki kemampuan untuk melakukan pengarsipan di pemerintahan desa.

b. Masyarakat dapat mendapatkan pelayanan yang lebih baik dari pegawai pemerintahan desa.

\section{METODE PELAKSANAAN}

\subsection{Kerangka Pemecahan Masalah}

Pengabdian ini dibuat untuk mengatasi permasalahan yang terjadi di kelurahan Merjosari, kecamatan Lowokwaru, kota Malang dalam tata kelola arsip sebagai bagian dari tertib administrasi. Dengan adanya permasalahan tata kelola dokumen dan arsip yang terjadi di Kelurahan Merjosari seperti kurangnya kesadaran akan kebutuhan tertib administrasi, kurangnya pengetahuan aparat kelurahan bahwa kearsipan itu penting, dan kurangnya keterampilan yang dimiliki oleh pengelola pemerintahan di tingkat kelurahan, maka tujuan kegiatan ini adalah sebagai berikut:
1. Memotivasi dan menumbuhkan kesadaran aparat kelurahan dalam pengelolaan dokumen dan arsip pemerintah sebagai pendukung kegiatan tertib administrasi

2. Meningkatkan pengetahuan dan wawasan bahwa tata kelola arsip adalah bagian dari tertib administrasi yang bermanfaat untuk peningkatan layanan terhadap masyarakat.

3. Meningkatkan kemampuan dan keterampilan tata kelola arsip aparat kelurahan.

Permasalahan yang harus dipecahkan agar pegawai kelurahan Merjosari dapat melayani masyarakat dengan lebih baik adalah kurangnya motivasi dan kesadaran aparat kelurahan dalam pengelolaan arsip pemerintah, kurangnya pengetahuan dan wawasan bahwa tata kelola arsip adalah bagian dari tertib administrasi, kurangnya kemampuan dan keterampilan tata kelola arsip aparat kelurahan yang bermanfaat untuk peningkatan layanan terhadap masyarakat.

Dari permasalahan yang ada maka diputuskan bahwa cara yang terbaik untuk memperbaiki kinerja pegawai adalah dengan pemberdayaan dan pelatihan/pendampingan. Pemberdayaan merupakan suatu usaha atau upaya yang dilakukan dalam rangka mengembangkan kemampuan dan kemandirian individu atau masyarakat dalam memenuhi kebutuhannya[2,3].

Pemberdayaan dilakukan dengan cara memberikan pendidikan mengenai pentingnya pelayanan publik yang efektif dan tata kelola arsip yang baik, dan juga memberikan pelatihan/pendampingan untuk melatih keterampilan aparat kelurahan dalam mengelola dokumen dan arsip penting yang dimiliki oleh kelurahan yang berguna bagi kemaslahatan masyakarat, bukti serta acuan pengambilan keputusan di masa mendatang.

Adapun kerangka pemecahan dari pelatihan ini digambarkan sebagai berikut:

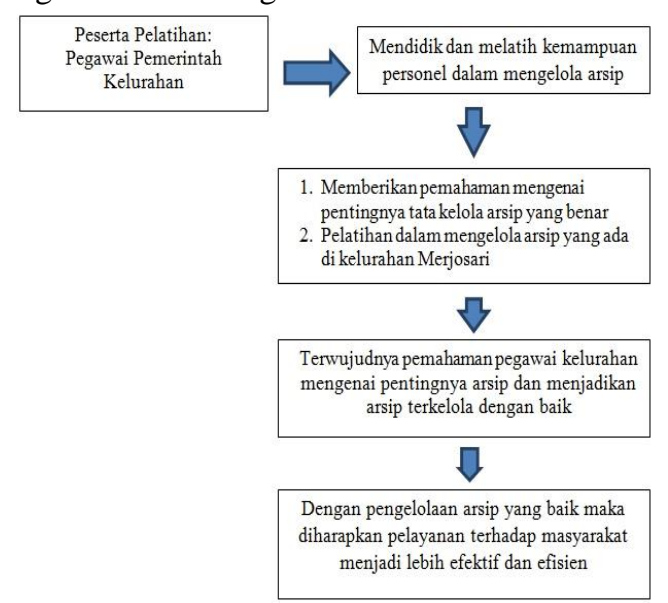

Gambar 1. Kerangka Pemecahan Masalah Tata Kelola Arsip Kelurahan Merjosari, Kecamatan Lowokwaru, Kota Malang

Melalui kegiatan pengabdian dengan judul "Pemberdayaan Pelayanan dan Tata Kelola Kearsipan 
di Kelurahan Merjosari Kota Malang" ini diharapkan peserta dapat mengaplikasikan pendidikan dan pelatihan yang mereka dapatkan dalam jangka panjang karena dokumen dan arsip yang dikelola bukan hanya untuk saat ini saja tetapi untuk seterusnya. Dengan kemampuan yang didapat dari pendidikan dan pelatihan/pendampingan, khususnya mengenai pengelolaan arsip, diharapkan peserta yang adalah pegawai kelurahan Merjosari dapat mengelola arsip dengan lebih baik dan mewujudkan pelayanan publik terhadap masyarakat menjadi semakin efektif dan efisien.

\subsection{Khalayak Sasaran}

Sasaran peserta pelatihan ini adalah pegawai pemerintahan desa, tepatnya Keadalah pegawai kelurahan Merjosari, Malang. Proses rekruitmen peserta pelatihan dilakukan dengan cara:

1. Survey lokasi pengabdian kepada masyarakat.

2. Sosialisasi pada sasaran pengabdian kepada masyarakat.

3. Bekerjasama dengan Lurah Merjosari, Malang.

4. Mendata pegawai Kelurahan Merjosari, Malang. Gambar di bawah ini adalah letak lokasi Kelurahan Merjosari, Lowokwaru, Malang:

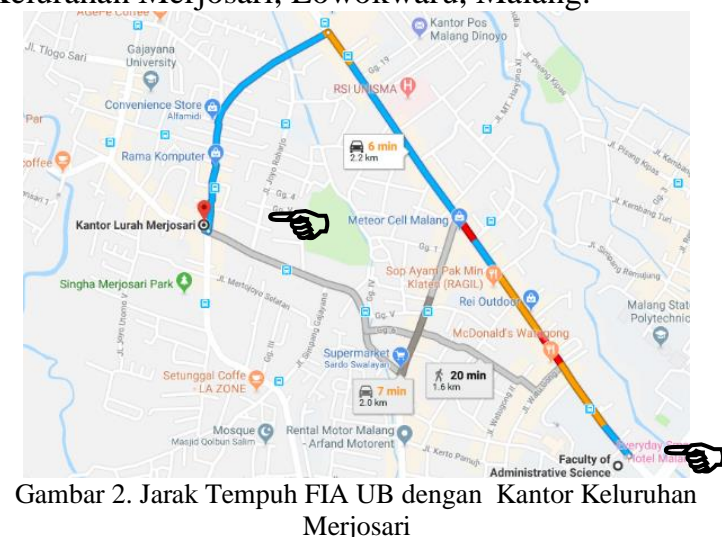

Jarak tempuh antara tempat peneliti dengan objek pengabdian masyarakat Kantor Keluruhan Merjosari yaitu 2,2 $\mathrm{KM}$ dapat ditemput dengan menggunakan kendaran mobil dalam waktu kurang lebih 6 menit.

\subsection{Metode Pelaksaan Kegiatan}

Untuk memecahkan masalah yang terjadi pada pemerintahan kelurahan Merjosari dan mencapai tujuan yang telah dijelaskan, metode yang tepat untuk digunakan dalam pengabdian ini adalah pendidikan dan pelatihan atau pendampingan. Pendidikan dilakukan dengan pemberian materi dan sosialisasi paparan mengenai tata kelola dokumen pemerintah, terutama pengelolaan arsip yang baik dan benar sebagai faktor penting dalam mendukung tertib administrasi terkait peningkatan layanan kepada masyarakat. Sedangkan pelatihan dan pendampingan pengelolaan dokumen pemerintah dilakukan setelah pemberian paparan dan motivasi mengenai tertib administrasi di kelurahan Merjosari. Pelatihan dan pendampingan tata kelola arsip berupa penataan, penyimpanan dan pemanfaatannya agar dapat ditemukan kembali dengan cepat dan tepat sesuai langkah pengelolaan arsip. Tim pengabdi juga memperkenalkan aplikasi pengelolaan arsip pemerintah desa/kelurahan.

Tim pengabdian kepada masyarakat ini terdiri dari tiga pakar di bidang masing-masing, Dr. Lely Indah Mindarti, M.Si, yang selanjutnya akan disebut sebagai Pengabdi 1, Dr. Choirul Saleh, M.Si, yang selanjutnya akan disebut sebagai Pengabdi 2, dan Aulia Puspaning Galih, MS, yang selanjutnya akan disebut Pengabdi 3.

Pengabdi 1 akan berfokus kepada pemberdayaan aparat kelurahan Merjosari. Materi mengenai pemberdayaan akan diberikan kepada para peserta, mulai dari definisi pemberdayaan, fungsinya hingga pentingnya bagi lembaga terkait, khususnya Kelurahan Merjosari, Kota Malang.

Pengabdi 2 akan lebih fokus pada pelayanan dan tata kelola pemerintahan. Materi mengenai pelayanan dan tata kelola pemerintahan akan dibahas secara mendalam agar peserta dapat benar-benar memahami pentingnya pelayanan dengan kaitannya pada tata kelola pemerintahan.

Pengabdi 3 berfokus pada teknis pelatihan pengelolaan arsip yang ada pada Kelurahan Merjosari. Pertama akan dijelaskan mengenai jenis arsip. Setelah mengetahui jenis arsip, hal selanjutnya yang dibahas adalah cara memproses arsip yang baik ${ }^{7}$.

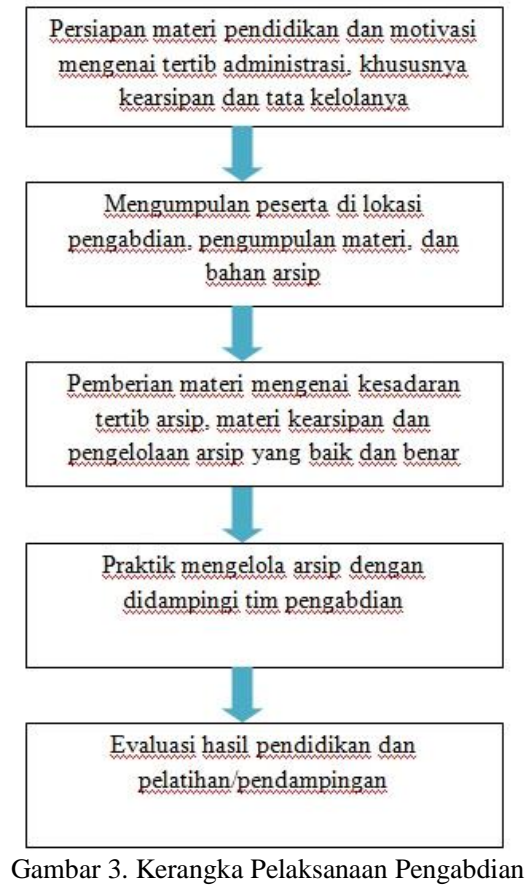

3.4 Evaluasi Kegiatan

Setelah semua metode pelaksanaan pengabdian dilaksanakan, selanjutnya evaluasi pelatihan akan diadakan setelah rangkaian acara telah selesai yaitu dengan dua cara: 
1. Tes teori yaitu berisi tentang pertanyaan yang berkaitan tentang materi mengenai pelayanan publik dan kearsipan yang telah diajarkan. Pertanyaan dapat diajukan secara langsung setelah pemaparan materi selesai dengan melalui kuis oral.

2. Praktik yaitu dengan menilai hasil praktik peserta sesuai yang diajarkan apakah sudah sesuai dengan tata cara dan langkah pengelolaan arsip yang benar.

Indikator keberhasilan pengabdian kepada masyarakat di kelurahan Merjosari, antara lain:

1. Peserta pelatihan memahami materi yang terkait dengan pelayanan publik dan tata kelola arsip.

2. Peserta memiliki kesadaran akan pentingnya tertib arsip yang dapat diukur dengan antusiasme terhadap materi yang telah diberikan.

3. Peserta dapat mengaplikasikan ilmu yang diperoleh dari pelatihan.

\section{HASIL DAN PEMBAHASAN}

4.1 Pelatihan Pemberdayaan Pelayanan dan Tata Kelola Kearsipan pada Kelurahan Merjosari, Malang

Pelatihan merupakan proses pendidikan jangka pendek yang menggunakan cara yang sistematis dan terorganisir. Para peserta pelatihan akan mempelajari pengetahuan dan ketrampilan yang bersifat praktis untuk tujuan tertentu. Selain itu, pelatihan juga merupakan suatu proses membantu orang lain dalam memperoleh wawasan dan ketrampilan teknis mengenai bidang tertentu, dalam hal ini adalah mengenai pelayanan, tata kelola pemerintah desa dan kearsipan pemerintah desa.

Pelatihan ini dipimpin oleh ketua pengabdian kepada masyarakat FIA UB, yaitu Ibu Dr. Lely Indah Mindarti, M.Si dan Lurah Merjosari, Bapak Drs, Abdullah. Kegiatan pelatihan dibuka oleh Bapak Lurah Merjosari dan dilanjutkan dengan pemberian materi mengenai pengelolaan pemerintah desa dan tata kelola kearsipan pemerintah desa.

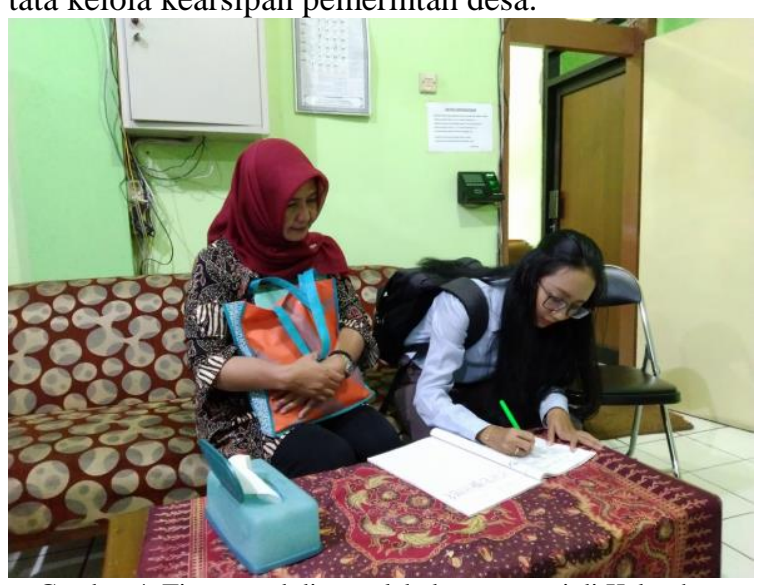

Gambar 4. Tim pengabdian melakukan presensi di Kelurahan Merjosari

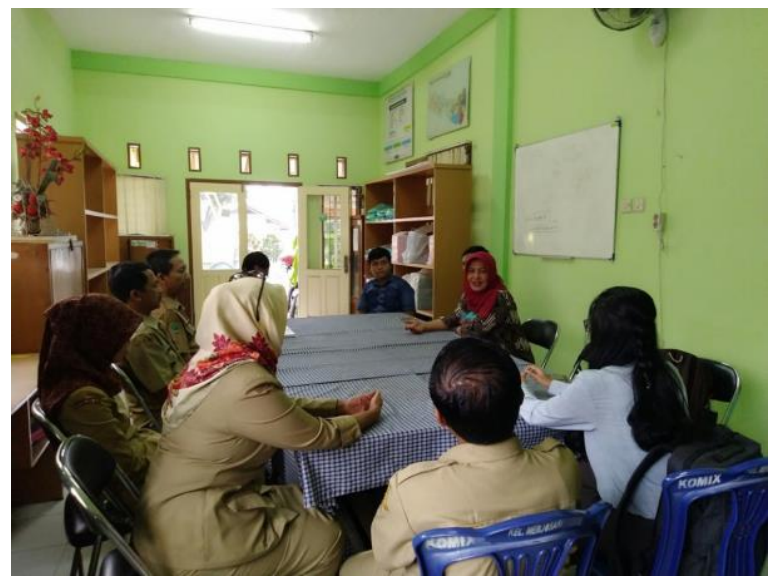

Gambar 5. Kegiatan pendampingan dan pelatihan di Kelurahan Merjosari

4.2 Pelaksanaan Pelatihan Pemberdayaan Pelayanan dan Tata Kelola Kearsipan di Kelurahan Merjosari

4.2.1 Pemberdayaan dan Pelayanan Pemerintah Desa

Berdasarkan pada UU No. 6 Tahun 2014 Tentang Desa dijelaskan bahwa Desa atau desa adat atau yang disebut dengan nama lain, selanjutnya disebut desa adalah kesatuan masyarakat hukum yang memiliki batas wilayah yang berwenang untuk mengatur dan mengurus urusan pemerintahan, kepentingan masyarakat setempat berdasarkan prakarsa masyarakat, hak asal usul, dan/atau hak tradisional yang diakui dan dihormati dalam sistem pemerintahan negara kesatuan Republik Indonesia.

Sesuai dengan Undang-Undang ini, kelurahan yang mana merupakan unit pemerintahan setingkat dengan desa yaitu Kelurahan Merjosari yang melingkupi kesatuan masyarakat yang terikat secara hukum dan memiliki luas wilayah yaitu $336 \mathrm{Ha}$ dan batas wilayah tertentu (Tabel 1), berwenang untuk mengatur dan mengurus urusan pemerintahan, seperti Urusan Pemerintah Wajib yang berkaitan dengan pelayanan dasar meliputi sebanyak 6 (enam) urusan antara lain : pendidikan, kesehatan, pekerjaan umum dan penataan ruang, perumahan rakyat dan kawasan pemukiman, ketentraman, ketertiban umum dan perlindungan masyarakat dan urusan sosial. Sedangkan yang tidak terkait dengan pelayanan dasar meliputi sebanyaak 18 (delapan belas) urusan antara lain : urusan tenaga kerja, pemberdayaan perempuan dan perlindungan anak, pangan, pertanahan, lingkungan hidup, administrasi kependudukan dan pencatatan sipil, pemberdayaan masyarakat dan Desa, pengendalian penduduk dan keluarga berencana, perhubungan, komunikasi dan informatika, koperasi, usaha kecil dan menengah, penanaman modal, kepemudaan dan olahraga, statistik, persandian, kebuadayaan, perpustakaan dan kearsipan, kepentingan masyarakat setempat berdasarkan prakarsa masyarakat, hak asal usul, dan/atau hak tradisional yang diakui dan dihormati dalam sistem pemerintahan negara kesatuan Republik Indonesia. 


\subsubsection{Tata Kelola Pemerintah Desa}

Dasar hukum:

1. Peraturan Daerah Kota Malang Nomor 8 Tahun 2008 tentang Organisasi dan Tata Kerja Kecamatan dan Kelurahan.

2. Peraturan Walikota Nomor 71 Tahun 2008 tentang Uraian Tugas Pokok, Fungsi dan Tata Kerja Kelurahan.

3. Peraturan Walikota Malang Nomor 3 Tahun 2012 tentang Pelimpahan Sebagian Kewenangan Walikota kepada Camat dan Lurah.

Pemaparan materi dan sosialisasi mengenai pengelolaan keuangan desa berdasarkan Permendagri No.20/2018 meliputi :

1. Anggaran Pendapatan dan Belanja Desa (APB Desa)

Pendapatan desa yaitu semua penerimaan uang melalui rekening desa yang merupakan hak desa dalam 1 (satu) tahun anggaran yang tidak perlu dibayar kembali oleh desa (Keuangan desa, 2018). Pendapatan desa terdiri dari: Pendapatan Asli Desa. Transfer meliputi Dana Desa; Bagian dari Hasil Pajak Daerah dan Retribusi Daerah Kabupaten/Kota; Alokasi Dana Desa (ADD); Bantuan Keuangan dari Anggaran Pendapatan dan Belanja Daerah Provinsi; dan Bantuan Keuangan dari Anggaran Pendapatan dan Belanja Daerah Kabupaten/Kota. Pendapatan lain-lain yaitu pemasukan lain yang diterima oleh desa.

2. Pengelolaan keuangan desa berdasarkan Pemendagri No 20/2018

Pengelolaan keuangan desa berdasarkan Pemendagri No 20/2018 memiliki struktur lebih kompleks dibandingkan Pemendagri No 113/2014 tentang Pengelolaan Keuangan Desa. Pengelolaan keuangaan desa berdasarkan Pemendagri No 20/2018 meliputi siklus pengelolaan keuangaan desa, penyusunan PerDes APB Desa, rancangan APB Desa serta bentuk laporan pertangungjawaban-daftar program sektoral, program daerah dan program lainnya yang masuk ke Desa.

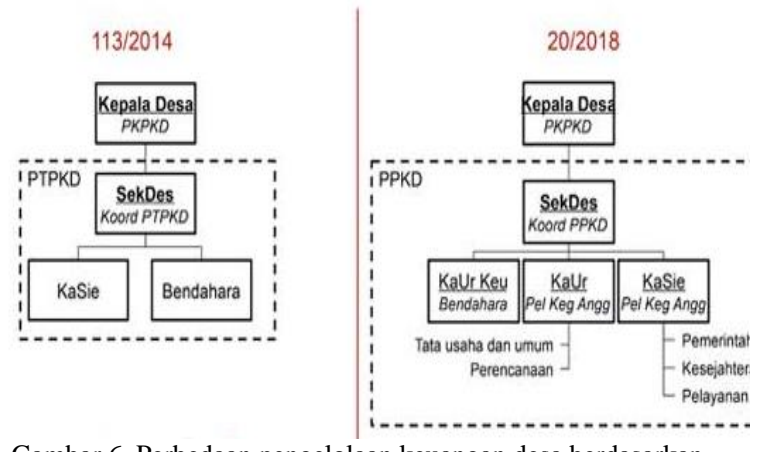

Gambar 6. Perbedaan pengelolaan keuangan desa berdasarkan Pemendagri No 113/2014 dan No 20/2018
Hasil pemaparan materi dan sosialasi ini diharapkan memberikan tambahan wawasan dan pengetahuan untuk aparatur Kantor Kelurahan Merjosari agar dapat menjalankan prinsip-prinsip mendasar mengenai pengelolaan keuangan desa berdasarkan No 20/2018 dan implementasinya pada Kantor Kelurahan Merjosari.

\subsection{Tata Kelola Arsip}

Tata kelola pemerintahan tidak akan berjalan lancar apabila penyimpanan dokumen-dokumen penting negara tidak disimpan dan ditata dengan baik, hal ini biasa disebut dengan kearsipan. Menurut Peraturan Menteri Dalam Negeri Republik Indonesia Nomor 135 Tahun 2017 tentang Tata Kearsipan di Lingkungan Kementerian Dalam Negeri dan Pemerintah Daerah, arsip adalah rekaman kegiatan atau peristiwa dalam berbagai bentuk dan media sesuai dengan perkembangan teknologi informasi dan komunikasi yang dibuat dan diterima oleh lembaga negara, pemerintahan daerah, lembaga pendidikan, perusahaan, organisasi politik, organisasi kemasyarakatan, perseorangan dalam pelaksanaan kehidupan bermasyarakat, berbangsa dan bernegara.

Arsip sendiri memiliki beberapa jenis, yaitu:

1. Arsip Dinamis adalah arsip yang digunakan secara langsung dalam kegiatan pencipta arsip dan disimpan selama jangka waktu tertentu.

Salah satu contoh arsip dinamis adalah surat keluar dan surat masuk yang beredar di lingkungan pemerintahan. Surat keluar dan surat masuk pun memiliki tata cara pengelolaannya sendiri. Pengelolaan surat masuk adalah seperti berikut:

a. Penerimaan surat: Mengumpulkan surat yang masuk, memeriksa kebenaran alamat, menandatangani bukti pengiriman, membuka surat dan memeriksa kelengkapannya .

b. Penyortiran surat

c. Pencatatan surat

d. Pengarahan surat

e. Penyimpanan surat

Sedangkan untuk pengelolaan surat keluar adalah sebagai berikut:

a. Mendapatkan arahan dari pimpinan

b. Membuat konsep surat

c. Membuat bentuk akhir surat

d. Meminta tanda tangan pemimpin

e. Mencatat pada buku registrasi keluar

f. Mendistribusikan surat

g. Persyaratan pembuatan: teliti, jelas, singkat dan padat, logis dan meyakinkan, baku.

h. Penomoran naskah dinas: kode dan sifat naskah dinas, nomor urut agenda, kode unit, tahun 
2. Arsip Aktif adalah arsip yang frekuensi penggunaannya tinggi dan/atau terus menerus.

Daftar berkas untuk arsip aktif sekurangkurangnya memuat:

a. Unit pengolah

b. Nomor berkas

c. Kode klasifikasi;

d. Uraian informasi berkas

e. Kurun waktu

f. Jumlah

g. Keterangan.

Daftar isi berkas sekurang-kurangnya memuat:

a. nomor berkas

b. nomor item arsip

c. kode klasifikasi

d. uraian informasi arsip

e. tanggal

f. jumlah

g. keterangan.

Unit pengolah menyampaikan daftar arsip aktif kepada unit kearsipan paling lama 6 (enam) bulan setelah pelaksanaan kegiatan.

3. Arsip Inaktif adalah arsip yang frekuensi penggunaannya telah menurun.

4. Arsip Statis adalah arsip yang dihasilkan oleh pencipta arsip karena memiliki nilai guna kesejarahan, telah habis retensinya dan berketerangan dipermanenkan, yang telah diverifikasi secara langsung atau tidak langsung oleh Badan Arsip.

Kemajuan teknologi dan informasi dapat dijadikan peluang bagi Kelurahan Merjosari untuk memberikan layanan berbasis teknologi diantaranya undangan elektronik atau surat digital yang ditujukan agar terwujud kemudahan dan efektifitas penyebaran informasi. Pada bidang Bendahara Pengeluaran, juga telah disediakan Web APBD untuk perencanaan keuangan, Sistem Informasi yang berhubungan dengan Daerah serta SIMBADA (Sistem Pengelolaan Barang Daerah).

Selanjutnya diharapkan Pemerintah Kelurahan Merjosari dapat menggunakan teknologi cloud computing sehingga informasi, data maupun dokumen yang dimiliki dapat disimpan dengan sistem keamanan memadai dan temu kembali informasi yang mudah dan cepat. Dari segi tata kelola kearsipan, Pemerintah Kelurahan Merjosari masih memiliki kendala, diantaranya terkait pengelolaan dokumen untuk mempermudah temu kembali informasi. Hal ini salah satunya dapat diselesaikan melalui penerapan sistem otomasi Arteri serta Jadwal Retensi Arsip.

Jadwal retensi arsip yang selanjutnya disingkat JRA adalah daftar yang berisi sekurang-kurangnya jangka waktu penyimpanan atau retensi, jenis arsip, dan keterangan yang berisi rekomendasi tentang penetapan suatu jenis arsip dimusnahkan, dinilai kembali, atau dipermanenkan yang dipergunakan sebagai pedoman penyusutan dan penyelamatan arsip. (UU No.43 Tahun 2009 tentang Kearsipan Bab 1
Pasal 1 poin 22). Adapun tujuan JRA ini adalah mewujudkan konsistensi dan kemudahan dalam hal penyusutan arsip, efisiensi penyusunan jadwal retensi arsip, dapat menjamin keselamatan bahan pertanggungjawaban nasional, dapat memudahkan temu kembali informasi serta sebagai perwujudan pemenuhan aturan perundang-undangan. Penerapan JRA ini dapat bermanfaat untuk menghemat waktu penelusuran informasi arsip, maupun dokumen, menghindari masalah hukum, efisiensi penggunaan arsip, serta dapat mengidentifikasi arsip yang memiliki nilai permanen.

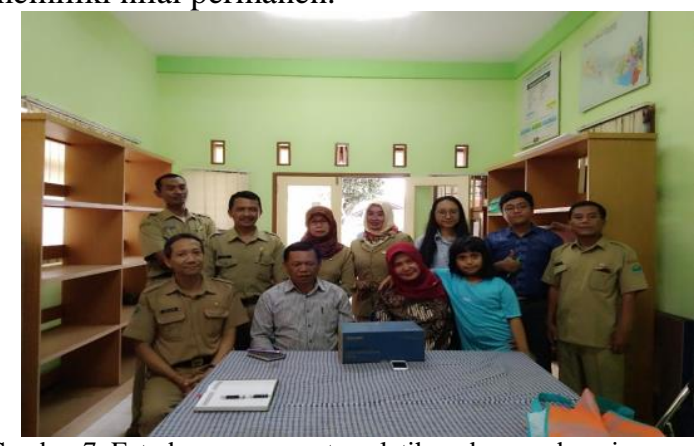

Gambar 7. Foto bersama peserta pelatihan dan pendampingan

\section{KESIMPULAN}

\subsection{Kesimpulan}

Kegiatan pengabdian masyarakat di Kantor Kelurahan Merjosari dilakukan oleh Tim Pengabdian kepada Masyarakat Fakultas Ilmu Administrasi Universitas Brawijaya melalui pendidikan, pelatihan dan pendampingan mengenai pemberdayaan pelayanan dan tata kelola kearsipan di Kelurahan Merjosari memberikan tambahan wawasan dan pengetahuan kepada seluruh aparatur Kantor Kelurahan Merjosari terkait pemberdayaan aparatur, pemberdayaan masyarakat, pelayanan public terhadap masyarakat, tata kelola pemerintahan desa, kearsipan dan program lainnya yang masuk ke Desa yang dapat diterapkan lebih baik lagi di Kelurahan Merjosari.

\subsection{Saran}

Aparatur Kelurahan Merjosari perlu menerapkan peraturan dan perundangan-undangan mengenai pengelolaan pemerintah desa dan kearsipan.

Kelurahan Merjosari perlu memberdayakan aparaturnya untuk tanggap terkait peraturan-peraturan dari pemerintah terkait pemberdayaan, pelayanan public, tata kelola pemerintah, dan kearsipan agar lebih efektif dalam melayani kebutuhan warga.

\section{DAFTAR PUSTAKA}

[1] Sulistyo-Basuki. 2003. Manajemen Arsip Dinamis.Jakarta: Gramedia

[2] Suhendra. 2006. Peranan Birokrasi dalam Pemberdayaan Masyarakat. Bandung: Alfabeta.

[3] Huraerah, Abu. 2011. Pengorganisasian dan Pengembangan Masyarakat: Model dan Strategi Pembangunan Berbasis Kerakyatan. Bandung: Humaniora.

Hardiansyah.2011. Kualitas Pelayanan Publik. Yogyakarta: Gava Media. 